\title{
THE INFLUENCE OF LARGE DOSES OF THYROID EXTRACT ON THE TOTAL METABOLISM AND HEART IN A CASE OF HEART-BLOCK *
}

J. C. AUB, M.D., AND N. S. STERN, M.D. BOSTON

The effect of the ingestion of thyroid extract on normal and myxedematous people has been studied by several observers. The general opinion seems to be that cases of myxedema and cretinism respond readily to thyroid extract by a considerable increase in basal metabolism, and that normal and obese people, while usually affected, respond to a less marked degree. DuBois ${ }^{1}$ reports a case of cretinism whose basal metabolism rose 20 per cent. in three and one-half days under the influence of thyroid extract.

The amounts of thyroid extract employed differ greatly in the investigations on normal and obese individuals. A patient with obesity studied by Magnus-Levy ${ }^{2}$ received the largest dose of thyroid extract that we know of - from 3 to $5 \mathrm{gm}$. daily for nineteen days. Anderson and Bergman ${ }^{3}$ used large doses, but only for one day before observations. Thiele and Nehring 4 used doses up to $0.9 \mathrm{gm}$. a day.

Observations vary as to the influence of thyroid on the total metabolism of normal and obese people. Some investigators report an increase, others none. Magnus-Levy ${ }^{2}$ found a rise from 10 to 25 per cent. following thyroid administration in three of five obese patients, and no rise in two. Stüve ${ }^{5}$ is reported to have found a rise in one patient after thyroid. Anderson and Bergman, ${ }^{3}$ after large doses the day before observation, found no rise in themselves except what they attributed to muscular exercise. Thiele and Nehring ${ }^{4}$ affirmed that thyroid tablets in all their cases caused a rise of gaseous metabolism.

\footnotetext{
* Submitted for publication Aug. 24, 1917.

* From the Medical Service and Respiration Laboratory, Massachusetts General Hospital.

1. DuBois, E. F.: Metabolism in Exophthalmic Goiter, The Archives INT. Med., 1916, 17, 915.

2. Magnus-Levy: Untersuchungen zur Schilddrüsenfrage, Ztschr. f. klin. Med., 1897, 33, 269.

3. Anderson and Bergman: Einfluss der Schilddrusen Futterung auf dem Stoffwechsel des Gesundes Menschen., Skand. Arch. f. Physiol., 1898, 8, 326.

4. Thiele and Nehring: Untersuchungen des Respiratarischen Gaswechsel unter dem Einfluss von Thyreoideapparaten und bei Anaemischen Zustanden des Menschen, Ztschr. f. klin. Med., 1896, 30, 41.

5. Stüve: Festschr., Frankfort a. M. 1896, 44.
} 
Means $^{6}$ found an increase in one obese patient, but two showed no rise after the administration of thyroid for five days. Jaquet and Svenson? found in some cases a rise in metabolism after thyroid, not in the basal observations, but in the extra energy given off following the ingestion of food. Their observations vary markedly from day to day, however, and the amount of thyroid given is not clear.

The present case is reported because of the marked effect of thyroid extract on the basal metabolism as well as on the auricular rate of the heart. It was possible to study auricles and ventricles separately owing to the presence of complete auriculoventricular dissociation.

\section{REPORT OF CASE}

History.-C. E. A., woman, white, single, aged 24, violin teacher. She had measles as a baby, and at 3 years scarlet fever and diphtheria simultaneously. She had no other infectious diseases. When 12 years old severe frontal headaches began which at first were biweekly, lasting from two to three days and associated with nausea, vomiting and abdominal pain. There have been no attacks for eight years. There has never been any syncope. She has been nervous and easily excited, quickly tired and never strong. She formerly felt cold all the time and had to wear extra clothes. Her skin and hair have always been dry.

Present Illness.-Eight years prior to admission she felt increasingly tired. Her arms began to ache, particularly the left; when worst, the pain occurred nightly and was so severe that she was kept awake and could not stand the pressure of the bed clothes. The attacks continue though gradually less severe.

For eight years she often noticed a sharp, severe pain in her left axilla, coming on after exertion. At times she had to stop walking because of severity of the pain and inability to breathe. About Nov. 1, 1916, a very intense attack seized her, but she kept on walking in spite of it. That night she could not move without pain.

During the previous seven years her physicians have said her heart rate was slow, usually 50 . Her mother said she had an irregular heart when 12 years old. Seven years prior to admission her physician gave her thyroid extract without result. This was done because her dry skin, sensations of cold and general condition offered the suggestion of myxedema. Two years later she took 5 grains of thyroid every other day and improved, but she "usually got better in winter." In June, 1916, her physician, after consultation, decided to push the drug until symptoms appeared. He increased the dose until she took for two weeks 26 or 27 grains of Burroughs, Wellcome \& Co.'s thyroid tablets a day, and for the next three weeks 28 grains a day. She said she had taken over 2,000 grains in from three to four months. Nevertheless, she had no tachycardia; her pulse was never over 72 and seldom over 62 . She had no headache, exophthalmos, diarrhea, loss of weight or sweating. Her catamenia were normal, and sleep was good.

In November, her physician called Dr. Edsall in consultation, who suggested this investigation.

Nov. 6, 1916. Physical examination showed a quiet, well developed and nourished girl. Her hands revealed a slight tremor. Her thyroid gland was

6. Means, J. H.: Studies of the Basal Metabolism in Obesity and Pituitary Disease, Jour. Med. Research, 1915, 32 (new series 27), 121; The Basal Metabolism in Obesity, The Archives Int. Med., 1916, 17, 704.

7. Jaquet and Svenson: Zur Kentniss des Stoff wechsel Fettsuchtigen Individuen, Ztschr. f. klin. Med., 1900, 41, 375. 
not palpable. Her heart apex by percussion was $10.5 \mathrm{~cm}$. to the left of the midline. The beat was forceful and the second sound sharp. There was a rather loud blowing systolic murmur everywhere. The heart was slow and block was suspected. The skin of her hands was soft and silky, her hair dry and fine. Her face was sallow and slightly coarse. Her eyes were not prominent. The basal metabolism was determined. Thyroid administration, 28 grains a day, was continued.

November 13. The hands were slightly swollen. The electrocardiograph confirmed the diagnosis of heart block. The basal metabolism was determined. Blood sugar 0.081 per cent. Thyroid continued.

November 16. Thyroid extract was omitted.

November 18. No thyroid was given on the third day. The basal metabolism was determined. Polygram (Fig. 1), electrocardiogram and roentgenogram were taken.

Roentgenographic report: Seven foot plate of the heart. The apex is $8 \mathrm{~cm}$. to the left of the median line; right border is $5.3 \mathrm{~cm}$. to right of the median line; total transverse diameter, $13.3 \mathrm{~cm}$.; greatest transverse diameter of great vessels, $6.5 \mathrm{~cm}$.; length of heart, $15.2 \mathrm{~cm}$; diameter at base, $10.4 \mathrm{~cm}$.; enlargement of heart to the right. Prominence of auricle.

November 20. Basal metabolism determined. Blood sugar 0.09 per cent.

November 21. Wassermann test negative.

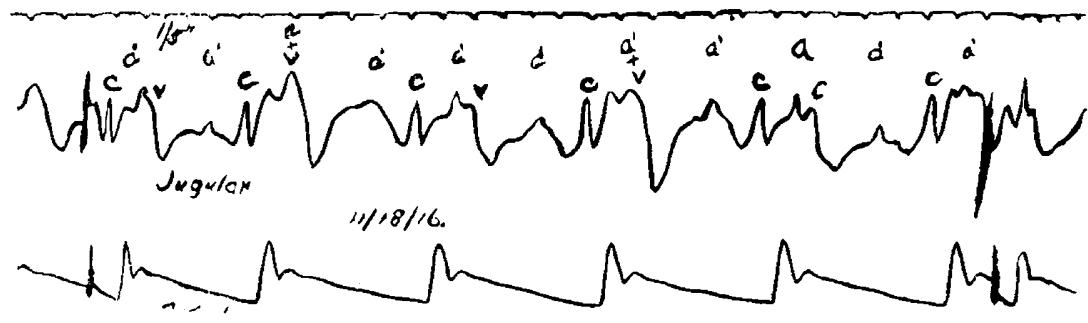

Fig. 1.-Polygram taken Nov. 18, 1916. Complete auriculoventricular dissociation. Auricular rate 108 per minute; ventricular rate 51 per minute.

December 4. No thyroid for nineteen days. She gets overtired now, cannot sleep, and feels cold all the time. Basal metabolism determined, and electrocardiogram taken (Fig. 2).

December 7. An attack of precordial pain, which radiated to her left arm, lasted several hours.

December 17. No thyroid for thirty-two days. Her skin is somewhat drier than before. Metabolism determined.

December 23. Electrocardiogram and polygram taken.

Jan. 27, 1917. Admitted to the Massachusetts General Hospital. Discharged February 4. Eight days prior to admission on climbing the stairs after one and one-half hours of violin practice, her heart began to beat forcibly, with an occasional strong beat, which her physician said was an extrasystole. This condition lasted a few days. This afternoon her left arm aches severely and she feels very tired.

Physical Examination.-The pupils were dilated but reacted normally; the heart apex was seen and felt in the fourth space $14 \mathrm{~cm}$. to the left of midline and $3 \mathrm{~cm}$. beyond the nipple; right border of dulness $2 \mathrm{~cm}$. to right; her feet were cold; there was no tremor of the hands. The chart showed a range of pulse between 51 and 64 . Urine and feces were normal; white count of blood, 16,700 ; differential count was normal.

January 28 . The basal metabolism was determined. No thyroid in seventyfour days. 
January 31. Electrocardiograms were taken before and after subcutaneous injection of one-fiftieth grain of atropin sulphate (Fig. 3).

February 1. Electrocardiograms were taken before and during right and left vagal and right ocular pressure, and immediately after walking 220 yards.

\section{DISCUSSION}

The basal metabolism determinations (Table 1) were made with the Benedict unit apparatus. ${ }^{8}$ The patient was fasting at least fourteen hours and was at compiete rest for at least one-half hour before, as well as during all observations. Every observation was checked by two observers.

The dose of thyroid ingested by the patient had been gradually increased by her physician until from 26 to 27 grains were taken daily for two weeks, and 28 grains a day for three weeks before she was seen by us and for ten days thereafter. She had thus taken about 1,000 grains in the course of five weeks, and over 2,000 grains in from 3 to 4 months.

As a result of these large doses, her average total basal metabolism was 54.5 and 52.3 calories per square meter per hour. These figures show a marked increase, 47 and 41 per cent., respectively, over the standard of 37 calories per square meter per hour found for a normal woman of her age. However, there were no other symptoms of hyperthyroidism than this increased metabolism and the increased auricular rate. There was no sweating, no nervousness, no diarrhea or exophthalmos. There was no loss of weight. On the contrary, she even claimed to have gained slightly.

After the omission of the thyroid the return to normal metabolism was very rapid. For sixty hours the metabolism continued at the same high level as before, namely, +40 per cent. But within the next fortyeight hours the metabolism dropped to +28 per cent. One week later, on the twelfth day after the omission of the drug, the metabolism had fallen to +11 per cent., a point practically within normal limits. Another week brought the variation to but 3 per cent. above normal.

As the height of the metabolism diminished the weight of the body increased, the net gain from November 13 to December 17 being $3.7 \mathrm{~kg}$.. about 8 pounds.

The respiratory quotients as obtained by the unit apparatus are not very accurate, and no great emphasis can be laid on them. Normally, they vary with a change in the percentage of foodstuffs burned. In this case they give no indication of a marked changed in the percentage of fat and carbohydrate utilized during and following thyroid ingestion.

Furthermore, there was no appreciable effect on the blood sugar by the thyroid medication. November 13, while thyroid was still being

8. Benedict, F. G.: Ein Universalrespirationsapparat, Deutsch. Arch. f. klin. Med., 1912, 107, 156. 


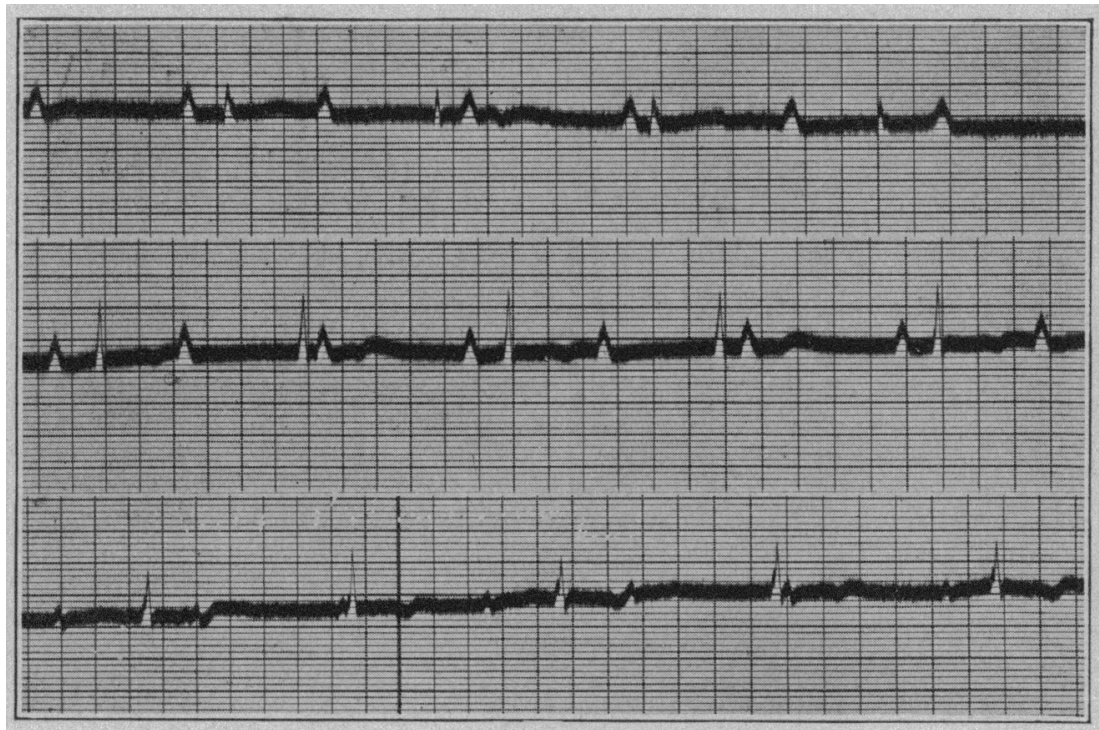

Fig. 2.-Electrocardiogram (Lead II), Dec. 4, 1916. Complete auriculoventricular dissociation; average auricular rate 71 ; average ventricular rate 50 .

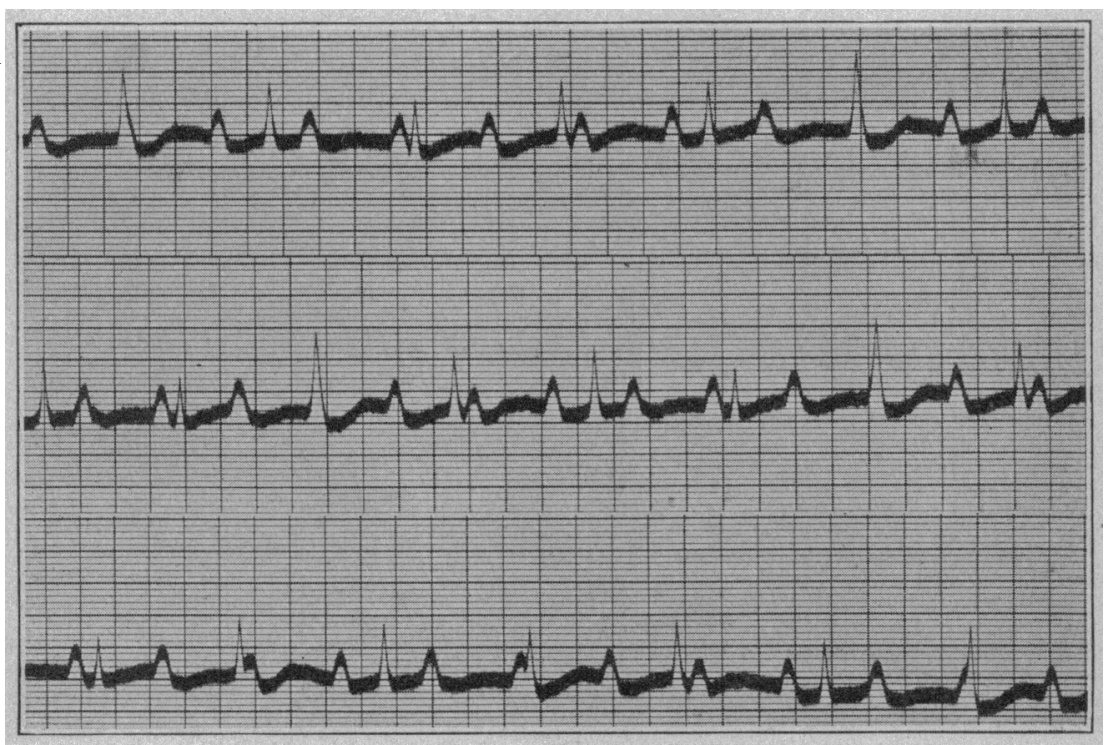

Fig. 3.-Electrocardiogram (Lead II), Jan. 31, 1917. Forty minutes after the subcutaneous injection of one-fiftieth grain of atropin sulphate. Auricular rates : upper record 116 , middle record 135 , lower record 120 ; average ventricular rate 74 . 


\begin{tabular}{|c|c|c|c|c|c|c|c|c|c|c|c|c|c|c|c|c|}
\hline 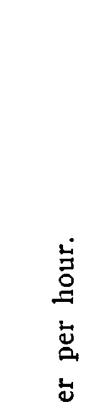 & 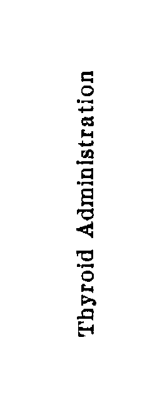 & & 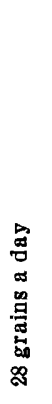 & & 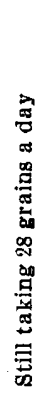 & & 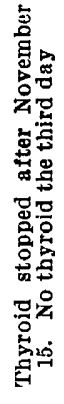 & & 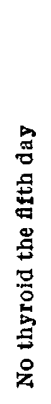 & & 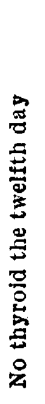 & & 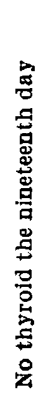 & & 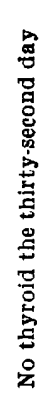 & 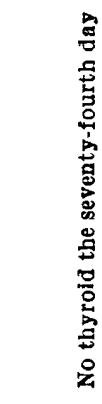 \\
\hline 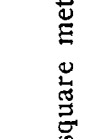 & 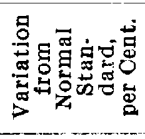 & & $\stackrel{5}{+}$ & & $\stackrel{F}{+}$ & & $\stackrel{9}{+}$ & & $\stackrel{\infty}{+}$ & & $\overrightarrow{7}$ & & $\begin{array}{l}\infty \\
+\end{array}$ & & $\ddot{z}$ & $\begin{array}{l}\infty \\
+\end{array}$ \\
\hline 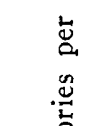 & 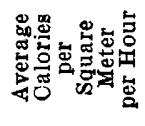 & & 管 & & đ̊ำ & & Fis & & $\stackrel{\infty}{:}$ & & $ت$ & & $\stackrel{\stackrel{N}{\infty}}{\infty}$ & & $\stackrel{\infty}{\mathfrak{*}}$ & 仓ें \\
\hline 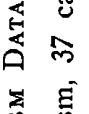 & 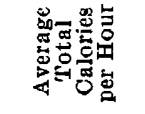 & & 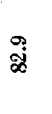 & & $\stackrel{\circ}{\dot{\infty}}$ & & 足 & & స్ & & $\overrightarrow{8}$ & & 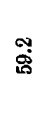 & & 8 & $\stackrel{\infty}{\mathscr{d}}$ \\
\hline 吾 & 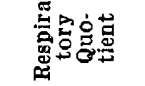 & & 変 & & : & & 今 & & 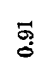 & & $\begin{array}{c}\mathbb{8} \\
0 \\
0\end{array}$ & & $\stackrel{\mathscr{0}}{\stackrel{\alpha}{S}}$ & & $\stackrel{\not 00}{\delta}$ & $\begin{array}{l}8 \\
0 \\
0\end{array}$ \\
\hline $\begin{array}{l}\stackrel{5}{2} \\
z\end{array}$ & 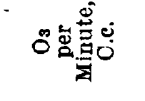 & 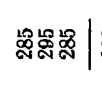 & $\mathbb{a}$ & 急胥 & 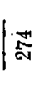 & 옹. & $\underset{\substack{\infty \\
亡}}{\stackrel{\infty}{\star}}$ & స్తి & $\mid$ & 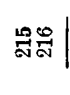 & $\stackrel{\infty}{*}$ & 嵒哭 & | & & 唹 & 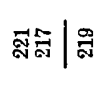 \\
\hline $\begin{array}{l}\text { in } \\
\text { 䔍 }\end{array}$ & 8̊ำ & สึజ్สి & జั & สี జ్లి & 絽 & ్ㅗㅇㅝ & ने & 䞸 & | สิ & 웜罢 & 兽 & 跑兽 & $\mid$ & 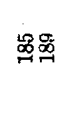 & $\mid \begin{array}{c}\mathbf{0} \\
\stackrel{9}{\sim}\end{array}$ & 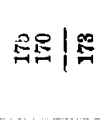 \\
\hline $\begin{array}{l}I \\
\dot{s} \\
\dot{\sigma}\end{array}$ & 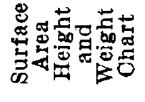 & $\vdots \vdots \vdots \vdots$ & 总 & $\vdots \vdots$ & $\stackrel{\text { 骂 }}{\rightarrow-1}$ & $\vdots \vdots$ & 晜 & $\vdots \vdots$ & $\stackrel{\mathscr{B}}{\mathfrak{g}}$ & $\vdots \vdots \vdots$ & 草 & & 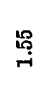 & & 歈 & $\vdots \vdots$ \\
\hline 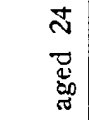 & 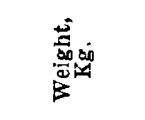 & $\vdots \vdots \vdots \vdots$ & 总 & $\vdots \vdots$ & i & $\vdots \vdots \vdots$ & $\stackrel{\infty}{\substack{0\\
}}$ & $\vdots \vdots$ & 点 & $\vdots \vdots$ & 点 & $\vdots \vdots$ & 象 & $\vdots \vdots$ & $\overrightarrow{0}$ & $\vdots \vdots \vdots$ \\
\hline & 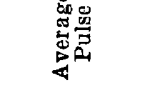 & 도요 & $\infty$ & 158 & |옹 & 点落 & 适 & 为哭 & 落 & 浞嵒| & 18 & ํㅜㅁ잉 & | 吕 & 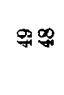 & | & उేత| \\
\hline & $\stackrel{\stackrel{\mathscr{Z}}{\tilde{R}}}{ }$ & $\begin{array}{l}\stackrel{0}{E} \\
\vdots \\
=\end{array}$ & 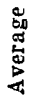 & $\stackrel{\stackrel{0}{90}}{\stackrel{9}{\Xi}}$ & 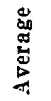 & 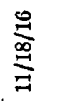 & 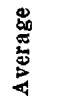 & 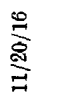 & 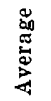 & 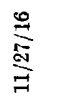 & 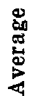 & $\frac{\infty}{\stackrel{9}{\pi}}$ & 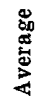 & $\stackrel{\stackrel{9}{N}}{\stackrel{9}{9}}$ & 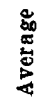 & 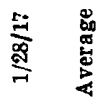 \\
\hline
\end{tabular}


administered, the blood sugar was 0.081 per cent., and November 20 , five days after omission of the drug, the blood sugar was 0.090 per cent., both normal figures.

From the cardiac point of view the case is one of the few of complete auriculoventricular dissociation in which the ventricular rate is 50 or over. Several cases in the literature show a high ventricular rate when the dissociation was due to digitalis poisoning, but only a few in which the cause of the block was organic. Lea, ${ }^{9}$ Hunt, ${ }^{10}$

TABLE 2.-Electrocardographic Rates

\begin{tabular}{|c|c|c|c|}
\hline & $\begin{array}{l}\text { Average } \\
\text { Auricular } \\
\text { Rate }\end{array}$ & $\begin{array}{l}\text { Average } \\
\text { Ventricular } \\
\text { Rate }\end{array}$ & Remarks \\
\hline $11 / 13 / 16, \ldots \ldots \ldots \ldots \ldots \ldots \ldots \ldots \ldots$ & 119 & 57 & Thyroid 28 grains a day \\
\hline $11 / 18 / 16 \ldots \ldots \ldots \ldots \ldots \ldots \ldots \ldots \ldots$ & 102 & 58 & No thyroid for 3 days \\
\hline $11 / 20 / 16 \ldots \ldots \ldots \ldots \ldots \ldots \ldots \ldots \ldots$ & 100 & 57 & No thyroid for 5 days \\
\hline $12 / 4 / 16 \ldots \ldots \ldots \ldots \ldots \ldots \ldots \ldots \ldots$ & 71 & 50 & No thyroid for 19 days \\
\hline $12 / 23 / 16 \ldots \ldots \ldots \ldots \ldots \ldots \ldots \ldots$ & 75 & 55 & No thyroid for 38 days \\
\hline $1 / 31 / 17 \ldots \ldots \ldots \ldots \ldots \ldots\left\{\begin{array}{c}103^{*} \\
96 \\
110\end{array}\right\}$ & 108 & 65 & Before atropin \\
\hline $1 / 31 / 17 \ldots \ldots \ldots \ldots \ldots \ldots\left\{\begin{array}{l}116 \\
135 \\
120\end{array}\right\}$ & 124 & 74 & After atropin, gr. $1 / 50$ \\
\hline $2 / 1 / 17 \ldots \ldots \ldots \ldots \ldots \ldots \ldots \ldots$ & 75 & 56 & Normal \\
\hline $2 / 1 / 17 \ldots \ldots \ldots \ldots \ldots \ldots \ldots \ldots$ & 75 & 56 & During right vagal pressure \\
\hline $2 / I / 17 \ldots \ldots \ldots \ldots \ldots \ldots \ldots \ldots$ & 75 & 56 & During left vagal pressure \\
\hline $2 / 1 / 1 i \ldots \ldots \ldots \ldots \ldots \ldots \ldots \ldots \ldots$ & 75 & 55 & During right ocular pressure \\
\hline $2 / 1 / 17 \ldots \ldots \ldots \ldots \ldots \ldots \ldots \ldots$ & 73 & 55 & $\begin{array}{l}\text { Immediately after walking } \\
220 \text { yards }\end{array}$ \\
\hline
\end{tabular}

* Auricular rates before and after atropin, as determined by the electrocardiograph.

TABLE 3.-POLYGRAPHIC RATES

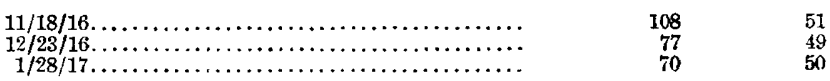

Windle, ${ }^{11}$ Neuhoff ${ }^{12}$ all report cases of complete auriculoventricular dissociation in which the ventricles beat at a rate of from 50 to 60 per minute, and even higher under certain circumstances.

The present case showed variations in pulse rate from 48 to 64 at the times of the metabolism studies. The electrocardiograph showed

9. Lea, Edgar: Complete Heart-Block with Higher Ventricular Than Auricular Rate, Lancet, London, 1915, 1, 1289.

10. Hunt, G. H.: Exhibition of Clinical Case, Lancet, London, 1913, 1, 1312.

11. Windle, J. D.: Permanent Complete Heart-Block, Heart, 1910, 2, 102.

12. Neuhoff, S.: Complete Heart-Block with Rapid, Irregular Ventricular Activity, Am. Jour. Med. Sc., 1913, 145, 513. 
variations in the ventricular rate from 50 to 65 , and forty minutes after the subcutaneous injection of one-fiftieth grain atropin sulphate, an increase to 74 .

The auricles, when the patient was still under the influence of thyroid, beat at the rate of 119 . November 18 , three days after thyroid was omitted, the auricular rate had fallen to 102 , two days later to 100 , and by December 4 , the nineteenth day after stopping the thyroid, to the normal rate of 71 . Thereafter the auricular rate was constantly about 75, except on January 31, when for some unexplained reason perhaps excitement - it rose to an average of 103 at the same time as the ventricular rate rose to 65 . The next day the auricles beat regularly at 75 .

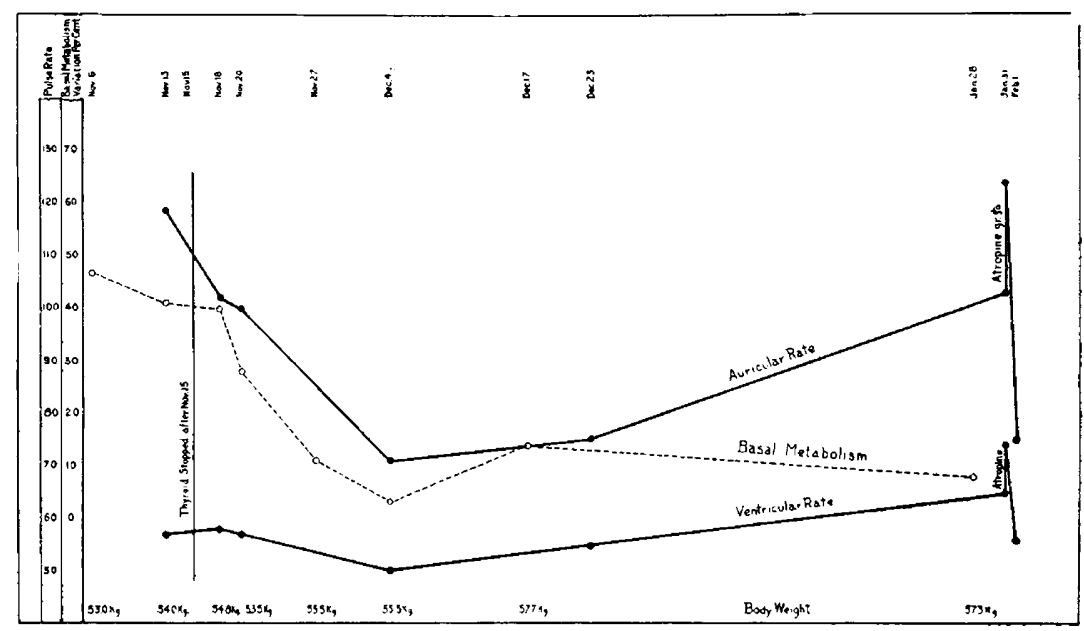

Fig. 4.-The influence of large doses of thyroid extract on the total metabolism and heart in a case of heart block.

The auricular rate curve and the metabolism curve (Fig. 4), though drawn to different scale, show a parallelism that is worthy of note.

The fact that the auricular rate was definitely modified by the ingestion of thyroid to give an auricular tachycardia, while the ventricular rate was in no wise influenced, seems to indicate that thyroid substance produces tachycardia through nervous channels and not by direct action on the muscle.

The subcutaneous injection of one-fiftieth grain atropin sulphate affected the rate of both auricle and ventricle. The auricles beat at the high rate of 135 (average 124) instead of at the previous high rate of 110 (average 103), an increase of about 23 per cent. (average 20 per cent.). The ventricular rate rose from 65 to 74 , an increase of about 
14 per cent. According to Frédéricq, ${ }^{13}$ this latter indicates that the heart-block is not absolute, that some vagus fibers, whose terminal filaments were paralyzed by the atropin, had been exerting an inhibitory action on the ventricles. Other mechanisms, however, are conceivable by which the phenomenon might be explained.

Right and left vagal pressure, right ocular pressure, and exercise produced no effect on either auricles or ventricles.

\section{SUMMARY}

A case of complete auriculoventricular dissociation is reported for the following reasons:

1. Thyroid extract was administered in increasing doses so that by the end of a period of from three to four months over 2,000 grains had been ingested. For the last four weeks of this period the dose amounted to 28 grains a day. The only effects observed from taking these large amounts of thyroid were an increase in the basal metabolism of 47 per cent. above normal and a rapid auricular rate of 120 . After the withdrawal of the thyroid the basal metabolism fell to normal limits within twelve days and the auricular rate within nineteen days (perhaps less). During the first months after the thyroid was omitted the body weight increased over 8 pounds.

The thyroid administration had no apparent effect on the respiratory quotient or the blood sugar.

2. The auricular rate was influenced by thyroid extract, but not the ventricular, which suggests that thyroid does not increase the heart beat by direct action on the muscle, but through nervous channels.

We wish to express our thanks to Dr. Edsall for permission to make these studies of his patient, and for his constant stimulating interest; and to Drs. J. H. Means and P. D. White for valuable aid and suggestions.

13. Frédéricq, Henri: Critique de l'emploi des éprouves de l'atropine et du nitrite d'amyle dans le diagnostic des bradycardies, Arch. d. mal. du coeur, Par., $1916,9,377$. 